\title{
Quinoa Oil
}

National Cancer Institute

\section{Source}

National Cancer Institute. Quinoa Oil. NCI Thesaurus. Code C72205.

The edible oil pressed from the seed germ of Chenopodium quinoa. Quinoa oil is used as a cooking oil and food ing redient as well as a source of vitamin E in skincare products. 